\title{
Cytokines Profile of Mice Infected by High and Low Virulences of Indonesian T. evansi Isolates
}

\author{
Sawitri $\mathrm{DH}^{1}$, Wardhana $\mathrm{AH}^{1}$, Wibowo $\mathrm{H}^{2}$ \\ ${ }^{1}$ Indonesian Research Center for Veterinary Science, JL. RE Martadinata 30 Bogor 16114 \\ ${ }^{2}$ Departement Parasitology, Faculty of Medicine, University of Indonesia, JL. Salemba Raya Jakarta \\ E-mail: dyah.haryuningtyas@gmail.com
}

(received 19-06-2017; revised 05-09-2017; accepted 11-09-2017)

\begin{abstract}
ABSTRAK
Sawitri DH, Wardhana AH, Wibowo H. 2017. Profil sitokin tikus yang terinfeksi dengan virulensi tinggi dan rendah isolat $T$. evansi Indonesia. JITV 22(3):151-164. DOI: http://dx.doi.org/10.14334/jitv.v22i3.1666

Surra pada ternak disebabkan oleh Trypanosoma evansi, yaitu protozoa darah homoflagella yang bersirkulasi secara ekstraseluler. Penyakit ini tersebar luas dikawasan Asia, Afrika, Amerika Selatan dan Tengah. Ditinjau dari aspek imunologis, tingkat keparahan surra pada hewan ternak (sapi) dan mencit yang diinfeksi trypanosoma berhubungan dengan respon inflamasi. Disisi lain lama hidup mencit tergantung pada regulasi sintesis Th1 dan sitokin proinflamasi seperti IFN- $\gamma$ dan TNF- $\alpha$. Penelitian ini bertujuan untuk melihat respon sitokin pro inflamasi IFN $\gamma$, TNF- $\alpha$ dan anti inflamasi IL-10 yang terjadi akibat adanya interaksi antara parasit dengan pejamu. Informasi ini dibutuhkan untuk perbaikan tatalaksana penanggulangan surra pada hewan. Sebanyak 30 ekor mencit dibagi dalam 3 kelompok (10 mencit/kelompok), yaitu kelompok 1 diinfeksi dengan T. evansi virulensi rendah (Pml287) dan kelompok 2 diinfeksi dengan virulensi tinggi (Bang87). Kelompok 3 tidak diinfeksi sebagai control. Serum mencit dikoleksi setiap 4 hari untuk pemeriksaan sitokin dengan metode ELISA. Hasil penelitian menunjukkan terdapat perbedaan profil sitokin proinflamasi dan antiinflamasi antara mencit yang diinfeksi isolat Bang 87 dan Pml 287. Kematian dini pada mencit yang diinfeksi isolat Bang 87 diduga akibat terjadinya sindrom respon inflamasi sistemik yang ditandai dengan peningkatan kadar IFN- $\gamma$ yang tidak dikompensasi secara cukup oleh antiinflamasi. Terjadinya anemia berkontribusi sebagai penyebab kematian pada mencit yang mendukung terjadinya kegagalan multi organ (multiple organ disfunction).
\end{abstract}

Kata Kunci: Surra, Trypanosoma evansi, Sitokin, IFN $\gamma$, TNF- $\alpha$, IL-10

\begin{abstract}
Sawitri DH, Wardhana AH, Wibowo H. 2017. Cytokines profile of mice infected by high and low virulences of Indonesian $T$. evansi isolates. JITV 22(3): 151-164. DOI: http://dx.doi.org/10.14334/jitv.v22i3.1666

Surra in livestock is caused by Trypanosoma evansi, a homoflagella blood protozoa that circulate in extracellular. This disease is widespread in Asia, Africa, South and Central America. According to the immunological aspect, the severity of surra in livestock and mice which infected by trypanosoma is associated with an inflammatory response. On the other hand, the survival time of mice depends on the regulation of Th1 synthesis and pro inflammatory cytokines such as IFN- $\gamma$ and TNF- $\alpha$. The aim of this study was to observe the responses of pro inflammatory (IFN $\gamma$, TNF- $\alpha$ ) and anti-inflammatory (IL-10) cytokines which result from interaction with parasites. This information is needed for improvements in the management of prevention of Surra in animals. A total of 30 mice were divided into 3 groups (10 mice/group). Group 1 was infected with low virulence (Pml287) and group 2 with high virulence (Bang87) T. evansi respectively. Group 3 not infected as control. Mice sera were collected in every 4 days for cytokine measurement using an Enzyme Link-Immunosorbent Assay (ELISA). The result showed a difference response of pro inflammatory and anti-inflammatory cytokine profile between mice infected by Bang 87 and Pml 287 isolate. Early deaths in mice infected by Bang 87 isolate were suspected as a result of the response of systemic inflammation syndromes characterized by elevated IFN- $\gamma$ levels that were not adequately compensated by anti-inflammatory. Anemia contributes to the cause of death in mice that support multiple organ failures (multiple organ dysfunction).
\end{abstract}

Key Words: Surra, Trypanosoma evansi, Cytokine, IFN $\gamma$, TNF- $\alpha$, IL-10

\section{INTRODUCTION}

Surra is a disease leading to high economy losses in the livestock farming business due to causing abortus, estrus cycle disorder of the female, body weight decrease, immune system depression and death (Payne et al. 1993; Payne et al. 1994; Jittapalapong et al. 2009).
The previous reports of many Diseases Investigation Centre (DIC) in Indonesia : Wates, Subang, Bukittinggi and Denpasar during the year of 2010-2014 indicated that the prevalent of surra in cattle, horse and buffalo was around $0.28 \%-69.3 \%$. From the point of view of immunology aspect, the severity level of surra on cattle and mice infected by trypanosome is related to the 
inflammation response (Maina et al. 2004; Mekata et al. 2013). While, the survival time of mice is depended on synthesis regulation of Th1 and cytokine proinflammation like IFN- $\gamma$ and TNF- $\alpha$ (Darji et al. 1996) and profile change of feedback negative of antiinflammatory cytokine and Th2 pattern (Namangala et al. 2001a). This is related to the expression of variant surface glycoprotein (VSG) of $T$. evansi which changes periodically. Magez et al. (1993) said that VSG released by $T$. evansi was identified as the main factor that induces the TNF- $\alpha$ and also known playing a role in excessive activating of macrophage. The study of the interaction between the host with infection of $T$. congolense, T. brucei and T. evansi is always associated to the species of the host with sensitivity difference, but until present there is no report how the response of the similar host due to the infection of $T$. evansi with different virulence so far. This information is needed to describe the different clinical manifestation which is not only caused by the species difference, but also due to different virulence level. Therefore, the effect of the divergence of virulence of $T$. evansi against its immune response on the same host is required.

Within the bloodstream system, trypanosome will be faced with natural immune response as the early defense of the host against the infection. Nature immune system consists of physical and chemical defense to the infection that is represented by the epidermis, cilial ephitel of respiration system, blood vessel endotel and mucosal surfaces by the antimicrobial secretion (Basset et al. 2003). Nature immune system is responsible to recognize and restrict the microbe/paracyte on the beginning of infection by activating the complement, phagocytosis and immune activation by different families from the pattern recognition receptors (PRRs). The nature immune response of the host focus on the introduction of conserved structure which is evolved on the microbe called pathogen-associated molecular pattern (PAMPs) coded as PRRs. One of PRRs families has been widely studied is Toll-like receptors (TLRs) (Akira et al. 2006; Medzhitov \& Janeway 2000). The most PAMPs identified on protozoa is glycosylphosphatidiylinositol (GPI) link activating the TLR 2 and 4 (Almeida \& Gazzinelli 2001) and the antimetilation DNA activating the TLR 9 (Debierre-Grockiego et al. 2003; Gazzinelli \& Denkers 2006) (Figure 2.9). Almeida et al. (2000) and Coller et al. (2003) described that the GPI molecule from the VSG will interact with macrophage which then inducing the proinflammation cytokine. Therefore, the first immune response of the host immune system is the pro inflammatory cytokine (IFN- $\gamma$, IL-1, IL-6) and NO excreted by the macrophage activity through classic path (Ca MФs). Furthermore, the DNA of trypanosome released when the parasite dies, is also known to activate the macrophage through the same path to secrete the other proinflammation cytokine such as TNF- $\alpha$, IL-12 dan NO (Shoda et al. 2001; Harris et al. 2006).

Severity of the disease occurred at the initial stadium of trypanosome infection on mice is signed by an increase in synthesis of pro inflammatory cytokines such as IFN- $\gamma$, TNF- $\alpha$ and the Th-1 pattern (Namangala et al. 2001a), while the survival time of mice depends on the expression of anti-inflammatory cytokines to do negative regulation and the Th-2 pattern (Darji et al. 1996). Mabbott et al. (1998) and Paulnock \& Coller (2001) described that IFN- $\gamma$ is the first pro inflammatory cytokine which has a crucial role in activating macrophage after being stimulated by parasite antigen. The activated macrophage will induce the production of pro inflammatory cytokine such as IL1 , IL-6 and TNF- $\alpha$ paling a role in parasitemia and host immune response (Paulnock \& Coller 2001; Gao et al. 2002; Magez et al. 2007). The increase in IFN- $\gamma$ level in the serum is useful to control parasitemia by activating the macrophage to clean the paracyte from the blood (Silva et al. 1992; Hertz \& Filutowicz 1998; Magez et al. 2006). Cytokine IFN- $\gamma$ produced by Th- 1 and $T$ $\mathrm{CD} 8+$ cells also have a role to stimulate the production of antibody IgG2a and $\mathrm{IgG} 3$ (component opsonization and microbial phagocytosis). An experimental study showed that high level of IFN- $\gamma$ and low parasitemia related to the animal resistance infected by $T$. brucei and T. evansi (Hertz \& Filutowicz 1998; Paim et al. 2011). Then it is described by Shi et al. (2003) that early motility on $\mathrm{BALB} / \mathrm{c}$ mice sensitive to the infection of $T$. congolense related to the increase in IFN- $\gamma$ synthesis leading to systemic inflammatory response syndrome (SIRS) (Figure 2.10).

The sensitivity to the infection was reported in mice deficiency to TNF- $\alpha$ infected by $T$. congolense (Naessens et al. 2004). Another study also reported that TNF- $\alpha$ produced by macrophage played a role in directly and undirectly eliminating the parasite by inducing the nitric oxide (NO). Nitric oxide is a free radical produced by macrophage synthesized from Larginine by NO synthase (NOS). This substantion has the effect of killing the parasite and destroying tissue function (spleen, liver, peritoneum, and central nervous system) (Eckersall et al. 2001; Reed et al. 1989; Kitani et al. 2002). The existence of selective inhibition by Th1 cell causes negative effect to NO. Specific antigen CD4+ Tr1 is possibly IL-10 to do negative regulation. The macrophage activity, especialy the kupffer cell in the liver increase significantly. The excisive SIRS lead to a death (Shi et al. 2003; Shi et al. 2004). Macrophage activation is marked by at least three factors: trypanosoma agocytosis, excessive production of IFN $\gamma$ and IL-10 production (Shi et al. 2005).

The IL-10 is a Th-2 cytokine related to the sensitivity of the host to protozoa. It can decrease the 
response of T cell by regulating the APC to decrease the secretion of TH-1 cell (IFN- $\gamma$ and IL-2), activation of IFN- $\gamma$ and suppressing the release of TNF- $\alpha$, IL- 1 and IL-6 by macrophage (Ghalib et al. 1993; Ralph et al. 1992). The IL-10 is needed to maintain a balance of protective and pathogenic immune responses during trypanosomiasis. No TL-10 is related to the decrease in lifetime and increase in inflammation in mice infected by T. brucei (Quan et al. 1999).

In addition, macrophage also produces IL-1. It is described by Sileghem et al. (1991) that IL-1 release by macrophage increase during acute phase on mice infected by $T$. brucei. This cytokine also induces acute phase of protein and stimulate the immune response mediated by lymphocyte. Other cytokine produced by macrophage and dendritic cell is IL-12 inducing Th-1 cell. In trypanosome infection, the production of IFN- $\gamma$ and IL-12 is related to the response of Th-1 and correlated to the resistence of host (Uzonna et al. 1998).

\section{MATERIALS AND METHODS}

\section{Ethic statement}

The protocol for the animal experiments was approved by Health Research Ethics Committee, Faculty of Medicine, Universitas Indonesia (Approval number 124/H2.F1/ETIK/2013).

\section{T. evansi isolates}

T. evansi isolates used in this study were Bangkalan 87 (high virulence) and Pemalang 287 (low virulence) isolates.

\section{Experimental animal}

As much as 30 DDY mice were divided into three groups. Group 1 (infected by Pml $287 \mathrm{~T}$. evansi isolatelow virulence), group 2 (infected by Bang $87 \mathrm{~T}$. evansi isolate-high virulence) and group 3 (control without infection). The infection of both $T$. evansi isolates was performed on the $1 \times 10^{4}$ paracytes/head of dose each intraperitoneal. The number of parasitemia was observed quantitatively in every two days of interval. Blood collection for the serum and PCV (hematocrit) examination was performed in every four days for 24 days.

\section{PCV test}

Sixty microlites of blood was taken by using microhematocrit (heparinized) through mice tail vein every four days interval. Both microhematocrit tips were closed by micro seal and then centrifuged for five minutes with $13,500 \mathrm{~g}$ speed until the blood and plasma were separated. Then, the hematicryte level was measured by microhematocrit reader (Hawsksley) and expressed in percent.

\section{Preparation of mice serum for ELISA}

Serum separation was performed by collecting blood from tail vena for about $90 \mu \mathrm{l}$ in the $0.6 \mathrm{ml}$ microtube without EDTA. The bleeding was stopped by wiping it with alcohol. The serum was isolated from mice blood which was incubated beforehand at room temperature for 30 minutes. After the bloodshed and clear liquid were formed, it then incubated for 30 minutes at $4^{\circ} \mathrm{C}$. The blood was centrifuged with $3.000 \mathrm{~g}$ of speed for 5 minutes at $4{ }^{\circ} \mathrm{C}$. All the serums were transferred into the new tube using a pipette. The second centrifugation was performed with the same speed and the pure serum was transferred to the new tube and stored at $-20^{\circ} \mathrm{C}$ until used.

\section{ELISA}

The proinflammation and antiinflammation cytokines were qualified using ELISA against antimouse IFN- $\gamma$, TNF- $\alpha$, and IL-10 (eBioscience, USA). The ELISA 96-well plate (Corning, USA) was coated using solution of $100 \mu \mathrm{l}$ of $0,5-4 \mu \mathrm{g} / \mathrm{ml}$ antimouse IFN- $\gamma(0.5 \mu \mathrm{g} / \mathrm{mL})$, TNF- $\alpha(1 \mu \mathrm{g} / \mathrm{mL})$, IL- $1 \beta(1 \mu \mathrm{g} / \mathrm{mL})$, IL-10 $(1 \mu \mathrm{g} / \mathrm{mL})$, and IL-12 $(1 \mu \mathrm{g} / \mathrm{mL})$ which was separately done by dissolving each cytokine on the dapar carbonate $\mathrm{pH} 9.6$ then incubated at $4^{\circ} \mathrm{C}$ for 24 hours. The plates were washed once using phosphate buffer saline (PBS) and added by the blocking buffer (PBS-0.5\% tween 20) as much as $200 \mu \mathrm{l} /$ well and incubated for 60 minutes at $37^{\circ} \mathrm{C}$. The blocking buffer was removed and the serum (mice serum) was diluted by 1:25 on the blocking buffer. It then was inserted into ELISA plate and duplicated. After incubated for 60 minutes at $37^{\circ} \mathrm{C}$, the plates then were washed six times using PBS $0.5 \%$ Tween 20 (Sigma Aldrich). Total of $100 \mu \mathrm{L}$ of Biotinilated antimouse conjugate with the concentration of $0.25-4 \mathrm{mg} / \mathrm{mL}$ : IFN- $\gamma(0.5 \mu \mathrm{g} / \mathrm{mL})$, TNF- $\alpha(0.5 \mu \mathrm{g} / \mathrm{mL}), \mathrm{IL}-1 \beta(1 \mu \mathrm{g} / \mathrm{mL}), \mathrm{IL}-10(1 \mu \mathrm{g} / \mathrm{mL})$, and IL-12 $(1 \mu \mathrm{g} / \mathrm{mL})$ which was diluted separately on the blocking buffer and added by ELISA plate and incubated for 60 minutes at $37^{\circ} \mathrm{C}$. After the 5-6 times of washing with PBS- $0.5 \%$ tween 20 , it was added by 100 $\mathrm{mL}$ Avidin-HRP (Horseradish peroxidase) that was diluted on the blocking buffer $(1: 1500)$ and incubated for 60 minutes at $37^{\circ} \mathrm{C}$. After 8-10 times of washing with PBS $0.5 \%$ tween 20 , it then was added to $100 \mathrm{~mL}$ of substrate/chromogen which was TMB (Tetramethylbenzidine). The plates were shaken and incubated for five minutes. When the color changed, the reaction was stopped by adding $100 \mathrm{~mL} \mathrm{2N} \mathrm{H2SO4}$ and 
incubated for 10 minutes. Then, the ELISA plate was read using ELISA reader on the wavelength of $450 \mathrm{~nm}$.

\section{Statistical analysis}

The ELISA result was descriptively and statistically analyzed. The determination of the difference of the response of cytokine of each group infected by high virulence (bang87), low virulence ( $\mathrm{Pml} 287$ ) isolates and control were used one-way analysis of variance (ANOVA) and non-parametric test of Mann Withney. Spearman Correlation test was used to determine the association between the parameters.

\section{RESULT AND DISCUSSION}

\section{Immunopathogenity of the T. evansi}

Normal PCV value on the mice used as a reference in this study was normal PCV value range from all mice before infection $(0 \mathrm{dpi})$ and the control group which is around $43-54 \%$. The PCV value under $43 \%$ was categorized as an anemia. Average value of PCV decrease in every experimental interval showed in Figure 1.

Group of mice infected by high virulence isolate (Bang87) the PCV value decreased by average $27.1 \%$ at $4 \mathrm{dpi}$, while the low virulence (Pml287) group by average $31.2-50.7 \%$ at the $8-24$ dpi respectively. This indicated that mice infected with $T$. evansi both high and low virulence had anemia. The control group had an average normal value of PCV until the end of the study (24 days).

The Bang87 group experienced simultaneous death at $5 \mathrm{dpi}$, so the next observation was performed only on the PML 287 and the control groups. Statistical analysis result showed that PCV level at 4 dpi was significantly difference $(\mathrm{P}<0.05)$ between the three groups (Bang87, PM1287 and control). The T-test result also showed a significant difference $(\mathrm{P}<0.05)$ between the $\mathrm{Pml} 287$ group and control at 8-24 dpi.

This study result showed no correlation between the level of parasitemia with hematocrit value $(\mathrm{P}>0.05)$. The level of parasitemia showed a fluctuation in every interval of experimental of mice infected by $\mathrm{Pml} 287$ (Figure 2), while the hematocrit value tended to decrease from the beginning to the end of the study (Figure 1). As well as between the hematocrit value

\section{PCV}

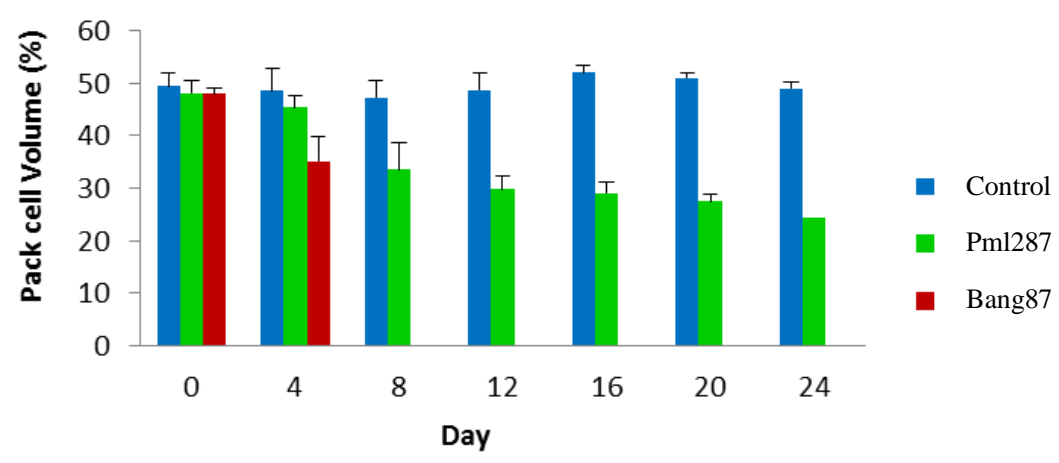

Figure 1. Packed Cell volume of high virulence (Bang 87) and Low virulence (Pml287) T. evansi infection in DDY mice at 24 days observation with 4 days intervals. * represent statistical difference between infected and control groups $(\mathrm{P}<0.05, \mathrm{n}=5 /$ each group). 


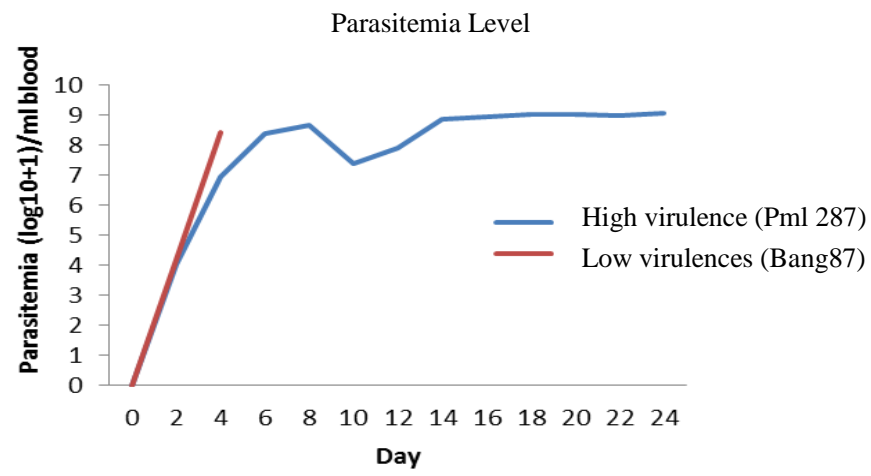

Figure 2. Parasitemia level of high virulence (Bang 87) and low virulence ( $\mathrm{Pml} 287)$ T. evansi isolates.

with the survival time did not show a correlation. The sensitive mice strain (DDY) infected by $T$. evansi low virulence isolate (Pml287) showed lower hematocrit value then the mice infected with $T$. evansi high virulence isolate (Bang87). However, the mice infected with Pml287 isolate survived up to 24 dpi.

\section{Profile of pro imflammatory (TNF- $\alpha$, IFN- $-\gamma)$ and anti implammatory (IL-10) cytokine level}

The result of ANOVA analysis showed that TNF- $\alpha$ level at 4 dpi was significantly different on those three treatments $(\mathrm{P}<0.05)$. The profile of TNF- $\alpha$ level on the Bang87 group incisively increased on the peak of parasitemia (4 dpi) sevenfold of the control (Figure 3). Then, this group show simultaneous death on 5 dpi so that the TNF- $\alpha$ level was not available for further observation.

The result of Mann Whitney analysis showed that the increase in TNF- $\alpha$ level during of 4-20 dpi was significantly different between the Pml287 group and the control $(\mathrm{P}<0.05)$. The $\mathrm{Pml} 287$ group showed a fluctuative profile of TNF- $\alpha$ level following its parasitemia pattern (figure 3 ) by increasing on 4 and 8 dpi by 2 and 3 fold each of the control. The decrease was at the $12 \mathrm{dpi}$. Then, there was an incisive increase on 16 dpi (about 4 fold of the control). The decrease in the TNF- $\alpha$ level are similar to the control occur at 20-24 dpi until dead at 26 dpi.
ANOVA analysis result at IFN- $\gamma$ level at 4 dpi also showed significant difference $(\mathrm{P}<0.05)$ between those three groups. The profile of IFN- $\gamma$ level on the Bang87 similar to TNF- $\alpha$ : the incisive increase in IFN- $\gamma$ at 4 dpi (sevenfold of the average level of the control) followed by the simultaneous mice death at 5 dpi.

According to the result of Mann Whitney analysis, it also showed that IFN- $\gamma$ level significantly different $(\mathrm{P}<0.05)$ between $\mathrm{Pml} 287$ and control at 8-20 dpi. Increase pattern of IFN- $\gamma$ of $\mathrm{Pml} 287$ group was fluctuative which was occure at 4-24 dpi. The increase of almost twofold of the control occured at 4 dpi then continued to increase into fourfold at $8 \mathrm{dpi}$. The IFN- $\gamma$ level decreased at $12 \mathrm{dpi}$ and then increasing fivefold at 16 dpi followed by a decrease to near the normal level at 24 dpi (Figure 4)

The ANOVA analysis showed that the IL-10 level at 4 dpi of Bang87 and Pml287 groups was significantly different $(\mathrm{P}<0.05)$ with the control. The IL-10 level on Bang87 showed an incisive increase at $4 \mathrm{dpi}$ by fourfold of the average level of the control followed by simultaneous death at 5 dpi.

The result of Mann Whitney analysis of the IL-10 level of Pml287 showed significant different $(\mathrm{P}<0.05)$ with the control during 8-20 dpi. The increase of the IL10 level of Pml287 began at 4 dpi by threefold of the control. This increase was maintained until reaching the peak at $16 \mathrm{dpi}$, then decreased at $20 \mathrm{dpi}$. After the decrease, the IL-10 level was not significantly different (P>0.05) with the control at $24 \mathrm{dpi}$ (Figure 5). 
TNF $\boldsymbol{\alpha}$

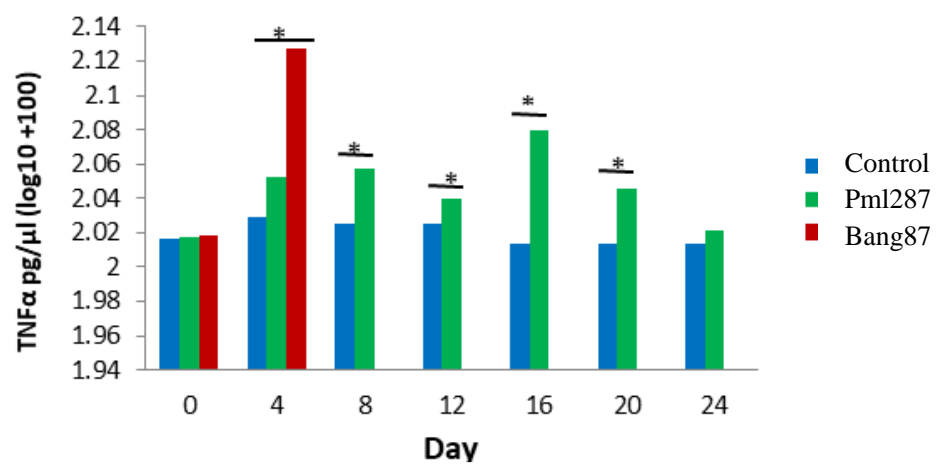

Figure 3. Serum level of pro inflamatory cytokines (TNF- $\alpha$ ) in DDY mice infected by high virulence (Bang 87 ) and low virulence (Pml 287) T. evansi isolate compared with uninfected controls. *represent statistical difference between infected and control groups $(\mathrm{P}<0.05, \mathrm{n}=5 /$ each group).

\section{IFN $\gamma$}

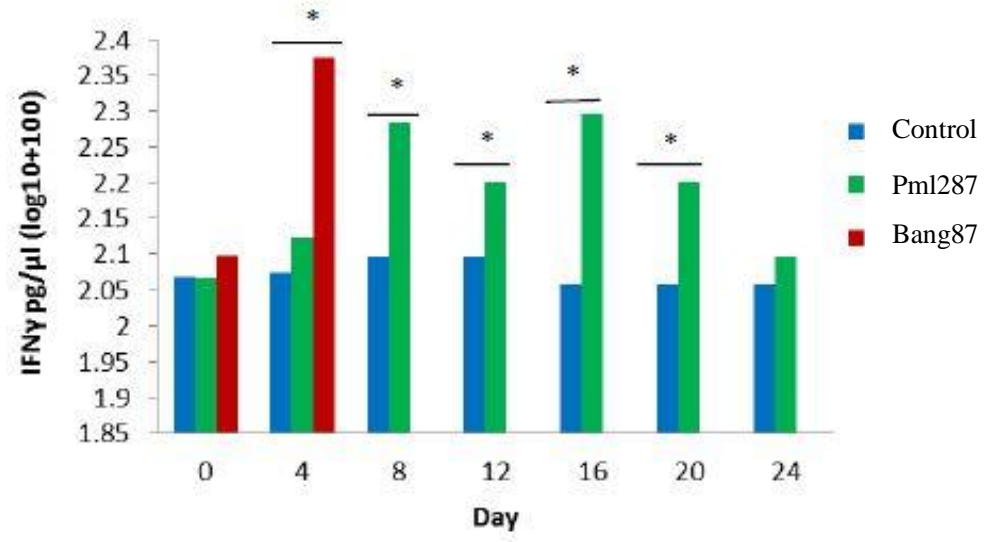

Figure 4. Serum level of proinflamatory cytokines (IFN- $\gamma$ ) in DDY mice infected by high virulence (Bang 87) and low virulence (Pml 287) T. evansi isolates compared with uninfected controls. * represent statistical difference between infected and control groups $(\mathrm{P}<0.05, \mathrm{n}=5 / \mathrm{each}$ group $)$.

\section{IL-10}

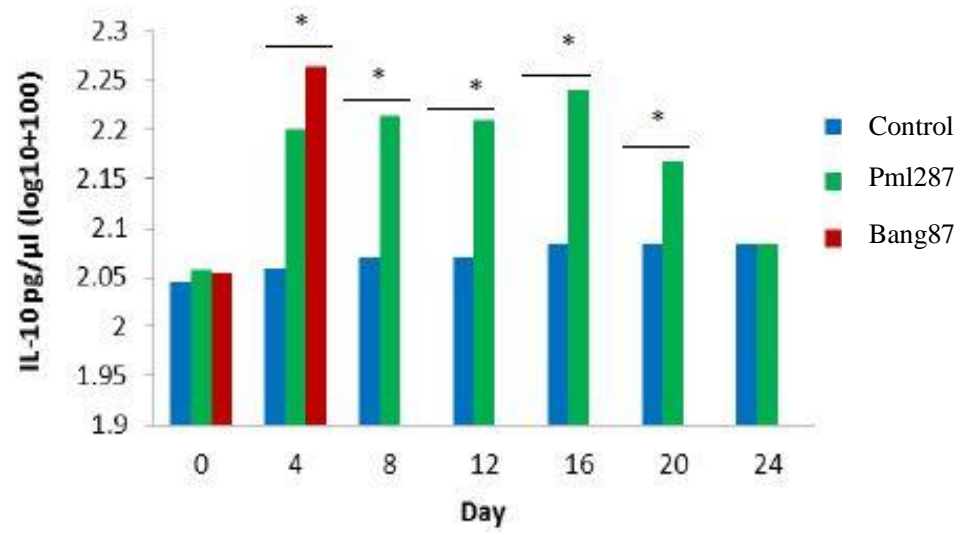

Figure 5. Median of IFN- $\gamma$ level on mice serum infected by T. evansi with high virulence (Bang87), low virulence (Pml287) and control (without infection of T. evansi). The *sign shows a significant difference between treatments $(\mathrm{P}<0.05)$ 


\section{The relationship of IFN- $\gamma$ level to the IL-10}

The correlation of the IFN- $\gamma$ and IL-10 showed that in the group infected by T. evansi isolate Pml287 and control showed an identic result with the balance of the IFN- $\gamma$ with IL-10. However, there was a slight increase in Il-10 level. In contrast to the Bang 87 group, the IL10 tended to decrease (Figure 6). The analysis result of spearman correlation between the IFN- $\gamma$ and IL-10 at 4 dpi of the mice infected by Bang87 isolate showed a

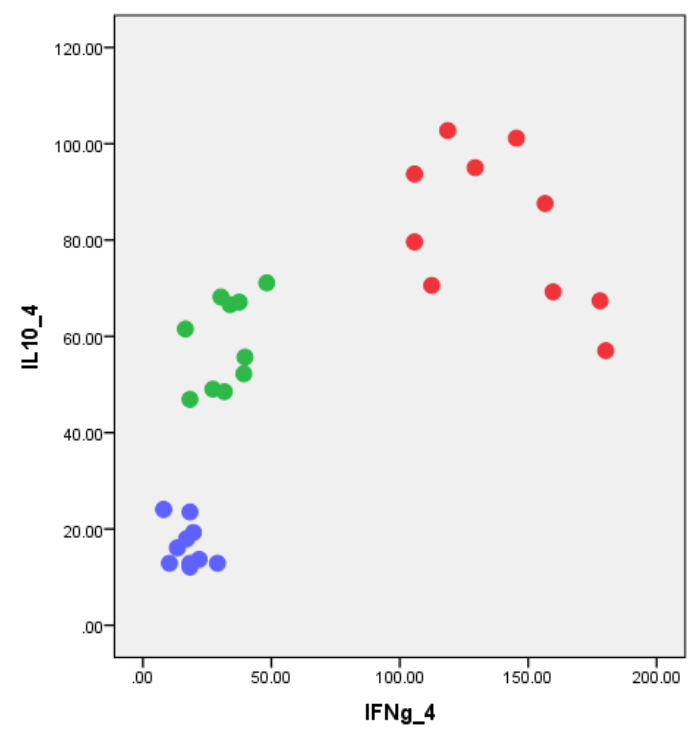

significant negative correlation $(\mathrm{P}<0.05)$. Analysis result showed that the increase of IFN- $\gamma$ level was not followed with the increase of IL-10. In the other word, higher IFN- $\gamma$, the more IL-10 level decrease. The analysis result on the Pml287 group showed a not significant positive correlation $(\mathrm{P}>0.05)$. This indicated that there was an increase in IFN- $\gamma$ level followed by an increase in IL-10 level (Figure 7).

Figure 7. Scatter diagram showing distribution pattern of control group and mice infected by T. evansi isolate Bang87 and Pml287 to the expression correlation of the IFN- $\gamma$ and IL-10.

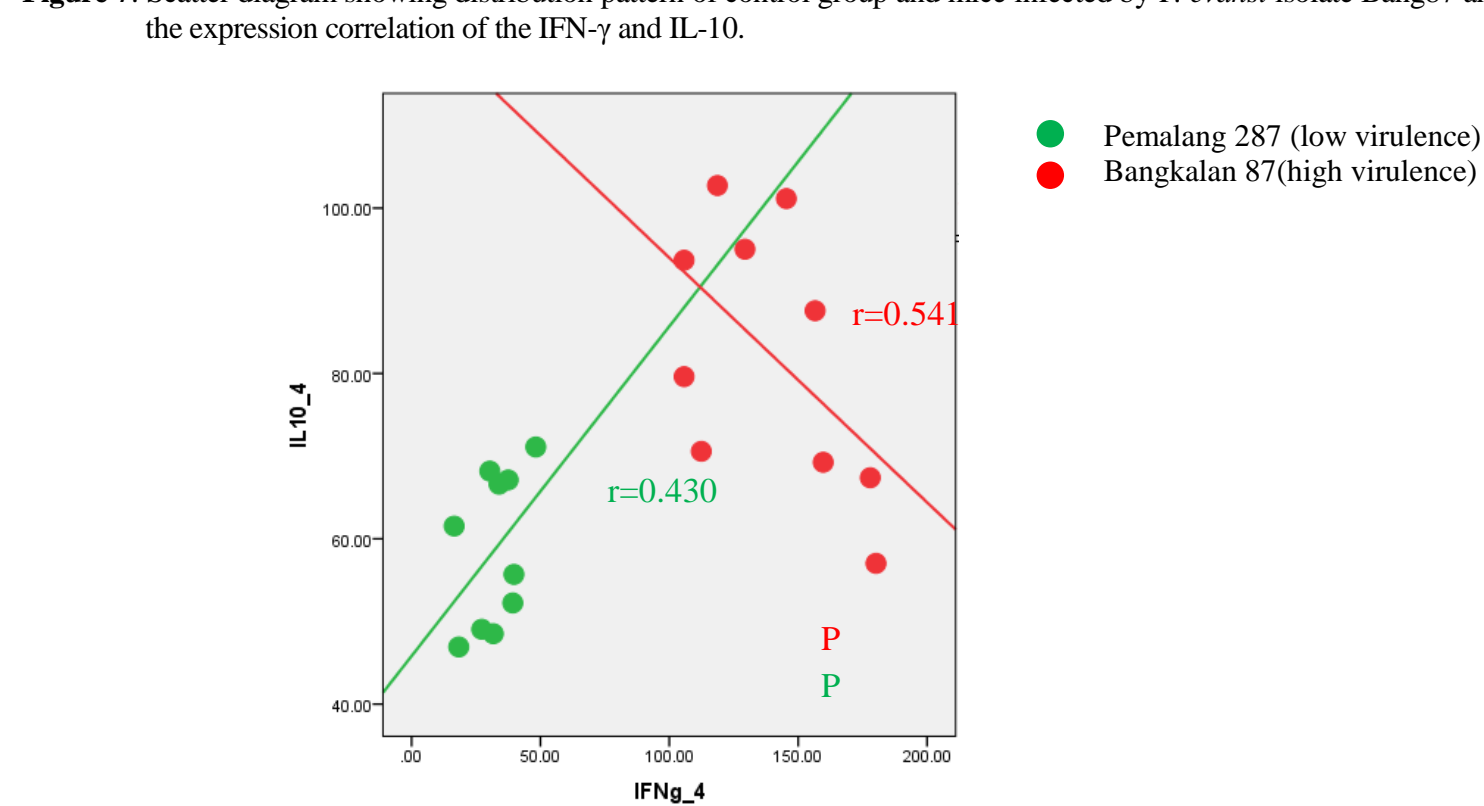

Control
Pemalang 287 (low virulence)
Bangkalan 87 (high virulence)

Figure 8. Scatter diagram showing distribution pattern of mice infected by T. evansi isolate Bang87 and Pml287 according to the analysis of expression correlation of IFN- $\gamma$ and IL-10. 


\section{Discussion}

\section{The difference of PCV profile between isolate $T$. evansi with high virulence (Bang 87) and low virulence (Pml 287)}

Verdillo et al. (2012) reported that all the mice infected by $T$. evansi will showing a significant decrease in PCV followed by anemia progressive. However, the decrease in PCV by $27.1 \%$ on mice infected by Bang87 isolate is expected not as the main cause of the early death but contributed to the multiple organ dysfunction (MOD). This can be explained by the observation result of the mice infected by Pml287 isolate. The decrease in PCV value of mice due to the infection was $31.2-50.7 \%$, but some mice were able to survive up to 28 days. However, Groenveld et al. (2008) stated that although the most cases of anemia are mild, the decrease of red blood cells amount will decrease the ability to absorb oxygen from lungs which in a long term it can cause the damage or multiple organ dysfunction including aritmia and heart failure. Differ with the surra, anemia related to the immunopathology is reported as the main cause of death in the Nagana case caused by $T$. vivax.

According to the parasitemia level, mice infected by Bang87 isolate experienced a decrease in PCV value at the peak of parasitemia. This incident was not found in mice infected with Pml287 isolate. The PCV value tended to decrease, but its parasitemia level was fluctuative until the mice dead at $28 \mathrm{dpi}$. This phenomenon is identic with the African trypanosomiasis case caused by $T$. congolense. The anemia was detected at the beginning of infection when the parasite was found in the blood circulation. Furthermore, anemia was maintained even until the parasite amount in the blood was low. This condition proves that anemia is not directly induced by the number of parasite in the blood, but is mediated by the cytokine. In many studies, it is stated that there is a correlation between anemia and inflammation (Naessens et al. 2005). This state is supported by Magez et al. (2004) who reported that anemia in a mouse infected by $T$. brucei is not correlated to the parasite amount and the survival time of the host.

One of the cytokines played a role in anemia process is tumor necrosis factor-a (TNF- $\alpha$ ). The anemia in a mouse infected by $T$. brucei rhodesiense is mediated by the TNF- $\alpha$ (Naessens et al. 2004). A study on the C57BL/6 mice strain which resistant to $T$. evansi and $T$. bruce $i$ proves that the development of anemia through the TNF- $\alpha$ mediated by TNF-R2 signal. This is supported by a study result of Magez et al. (1999) who proved that TNF- $\alpha$ is a key moderator involved in parasitemia control process and a pathology damage on mice infected by $T$. brucei. This result is in accordance with the statement that the peak of parasitemia of mice infected by Bang87 isolate at 4 dpi was increased of TNF- $\alpha$ level, otherwise, this causes the decrease of PCV value (anemia). Even though statistically did not show any significant correlation $(\mathrm{P}>0.05)$ between the TNF- $\alpha$ level and parasitemia amount and the decrease of PCV value, there was a tendency PCV value and TNF- $\alpha$ level to be inversely proportional. An increase in the TNF- $\alpha$ level in mice infected by Bang87 isolate was up to sevenfold compared to the control. In contrast with this result, the mice infected by $T$. congolense shows that the TNF- $\alpha$ did not play an important role in the anemia (Naessens et al. 2005).

A role of TNF- $\alpha$ in the anemia process also occurred in the mice infected by Pml287 isolate. This Profile pattern of the TNF- $\alpha$ on mice was different to the Bang87 isolate. An increase in the TNF- $\alpha$ level in mice infected by Pml287 isolate was fluctuative by around twofold to fourfold compared to the control following its parasitemia pattern (Figure 1). However, the PCV value tended to decrease since the first peak of parasitemia until the mice dead (at $26 \mathrm{dpi}$ ). The TNF- $\alpha$ contributes in the anemia process at different level due to its activity on hemopoiesis by decreasing erythropoietin and inhibiting proliferation of the precursor cell (Jelkmann 1998) or playing a role in hyperactivation of macrophage system (Larroche \& Mouthon 2004).

\section{Pro-inflammatory cytokine profile (IFN- $\gamma$, TNF- $\alpha$, ) and anti-inflammatory (IL-10) cytokine profile in mice infected with Bang 87 and Pml287 T. evansi isolate}

Response pattern of cytokine during parasite infection is able to describe interaction between the parasite agent and host sensitivity (Sher \& Coffman 1992). The cytokine is an immune system regulator which works by keeping up the balance between the type 1 (pro-inflammatory cytokine) and type 2 (antiinflammatory cytokine) in influencing a manifestation of a disease. On trypanosomiasis infection, lymphocyte produces IFN- $\gamma$ as a response to the parasite antigen which then will activate macrophage to increase its ability in destroying organism through phagocytosis. The activated macrophage will induce the production of TNF- $\alpha$ and IL-10 cytokines. Those cytokines have an important role in replicating the parasite of the host (Magez et al. 2007).

\section{Isolate Bang 87 (high virulence)}

This study results showed that mice infected by Bang87 and Pml287 isolate increased regulation of IFN- $\gamma$ and TNF- $\alpha$ during infection period. The mice infected with isolate Bang87 showed extreme 
production of IFN- $\gamma$ and TNF- $\alpha$ (by sevenfold of the control respectively) on the peak of parasitemia (4 dpi). Magez et al. (1997) said that pro-inflammatory cytokine such as IFN- $\gamma$ and TNF- $\alpha$ contributes to the defense mechanism of the host against an infection. On the infection of T. brucei and T. congolense, IFN- $\gamma$ and TNF- $\alpha$ cytokine are reported having an important role on the parasitemia control and survival time of the host (Hertz \& Filutowicz 1998; Magez et al. 2007; Naessens et al. 2004). However, an excessive cytokine response can be harmful the host even causing death (Magez et al. 1999; Magez et al. 2004).

The increase of pro-inflammatory cytokine level was also followed by an increase in anti-inflammatory (IL-10) cytokine. The IL-10 level increased fivefold from the control at $4 \mathrm{dpi}$. However, the IL-10 increase is allegedly unable to offer sufficient negative control due to the incisive increase of the pro-inflammatory cytokine (IFN- $\gamma$ ). This condition is allegedly as the main cause of mice death in a short time (5 dpi) due to a cytokine storm

Shi et al. (2003) said that early mortality of sensitive mice $(\mathrm{BALB} / \mathrm{c})$ infected by $T$. congolense is triggered by the excessive synthesis of IFN- $\gamma$ leading to a Systemic Inflammatory Response Syndrome (SIRS). This phenomenon is initiated by the fagositosis trypanosome by kupffer cell which ultimately causes swelling and apoptosis of the cell kupffer, lesion focal of liver parenchyma cell, capiler swelling, hypotension, body temperature decrease and the host becomes limp (Shi et al. 2003; Shi et al. 2006). Then it is stated that the SIRS is related to the excessive production of the pro-inflammatory cytokine such as TNF- $\alpha$, IL-6, IL-12 and IFN- $\gamma$ (Kaushik et al. 2000; Stijlemans et al. 2010; Uzonna et al. 1998). It is reinforced by Abbas \& Litchman (2009) who said that TNF- $\alpha$, IL-1 and chemokine are the main cytokine involved in monocyte and neutrophil to the location of the infection. The high concentration of the TNF- $\alpha$ can cause a thrombus on the surface of endothelial, increasing blood pressure due to the decrease of heart muscle contraction, dilatation and blood vessel puncture and body metabolism failure.

The SIRS phenomenon is also reported on the severe infection case of gram-negative bacteria leading a deadly clinical syndrome called "septic shock" (Abbas \& Litchman 2009). Coldewey et al. (2013) said that sepsis is a complex clinical symptom aggregate caused by the systematic response of the individual in facing the infection which manifests on various clinical symptoms. This syndrome is a cause of the MOD or severe sepsis leading to the death. The mechanism causing the sepsis is cardiovascular dysfunction including the microvascular disfunction, the activation of leucocyte and the effect of excessive production of a pro inflamatory cytokine such as TNF- $\alpha$ and IL-1 $\beta$ (Krishnagopalan et al. 2002).
The cytokine storm is also proved by Guilliams et al. (2009) by knocking out the IL-10 gen on the C57BL/6 resistant mice infected by $T$. brucei brucei which causing an early death. Therefore, the IL-10 is a very important cytokine to control the emergence of pro inflammatory cytokine storm causing the early death due to the effect of SIRS.

In terms of inflammation signal activation by nature immune system cell, the failure of compensation of the IL-10 may be caused by the blocade activity of IFN- $\gamma$ against the certain protein on the activation process of IL-10. Saraiva \& O'Garra (2010) described that IL-10 expression of macrophage and dendritic cells can be induced through TLR or non-TLR pattern (Figure 9.a). Activation of TLR and its molecule adaptor, the myeloid differentiation primary-response protein 88 (MYD88) and TIR-domain-containing adaptor protein inducing IFN- $\beta$ (TRIF) activate the extracellular path of signal-regulated kinase 1 (ERK1) and ERK2, p38 and

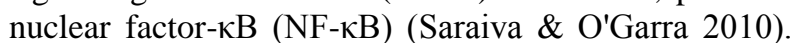
The activation of this path results in an induction of the expression of the pro-inflammatory (IFN- $\gamma$ ) and antiinflammatory (IL-10) cytokine (Saraiva \& O'Garra 2010). While, the activation path of the non-TLR through dendritic cell (DC) specific ICAM3-grabbing non-integrin (DC-SIGN) and RAF1 that play a role to increase the induction of TLR2 for then producing IL 10. On the macrophage, the role of nucleotide-binding oligomerization domain 2 (NOD2) signal on the IL-10 induction is similar with the TLR2.

This study results showed the IL-10 production did not compensate the production of IFN- $\gamma$ in mice infected by Bang87 isolate at 4 dpi which was a day before the dead at 5 dpi. That is allegedly to be led by two factors (Figure 9). The first factor (Figure 9a) is the presence of positive and negative feedback interference of IL-10 on macrophage the expression of dualspecificity protein phosphatase 1(DUSP1) which will reduce IL-10 production is not compensated by positive feedback increased expression regulation of locus 2 a progression tumour (TPL2) to increase the production of TL-10. The second factor is the high level of IFN $\gamma$ will disturb the path of phosphoinositide 3-kinase (PI3K)-AKT which will release glycogen synthase kinase 3 (GSK3). Normally, the GSK3 will block the expression of IL-10 with its action on the transcription factor of cAMP response element-binding protein (CREB) and activator protein 1 (AP1) where the Il-10 production is inhibited by IFN- $\gamma$ through its effect on PI3K (Saraiva \& O'Garra 2010).

\section{Pml 287 T. evansi isolate (low virulence)}

The mice infected with Pml287 had longer survival time (more than 18 days). This condition also occurs in resistance mice (C57BL/6) infected with $T$. brucei 
(Namangala et al. 2001b). The IFN- $\gamma$ and TNF- $\alpha$ level slowly increased and fluctuated following the level of its parasitemia. At the peak of parasitemia, the level of IFN- $\gamma$ increased, and then decreased where there is a relapse. That pattern indicates a regulation of cytokine through negative feedback so that the cytokines do not harm the physiology of the host which is able to extend the life of mice. An increase in IL-10 level was estimated to able to maintain the balance of the pro inflammatory cytokine (IFN- $\gamma$ ). This mechanism is able to extend the average survival time of mice. The decrease in IL-10 level followed by death started from 20 dpi. Namangala et al. (2009) and Noël et al. (2002) said that the response of type- 1 cytokine (IFN- $\gamma$, TNF$\alpha$ ) which then turned into type-2 cytokine (IL-10) related to the characteristic of resistance phenotype of mice. An important role of IL-10 on trypanotolerant has been proved well using mouse deficient to gen IL-10 on the T. brucei model (Namangala et al. 2001b). That statement has been confirmed by Shi et al. (2003) who provided anti IL-10 receptor therapy on mice C57BL/6 infected by $T$. congolense. This therapy is able to stimulate a neutralization of the IFN- $\gamma$ with the antibody anti IFN- $\gamma$, so that the mice can survive longer. A similar result is also reported by Guilliams et al. (2009) who proved a fact that the mice deficient to IL-10 shows immunopathology and reduce its survival time drastically because mice can not control the production of very strong immune response of the type-1 (proinflammatory) cytokine at the beginning of infection.
Myleoid

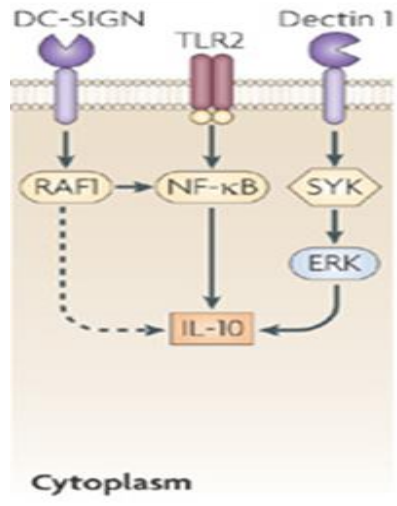

Macrophages and myeloid DCs

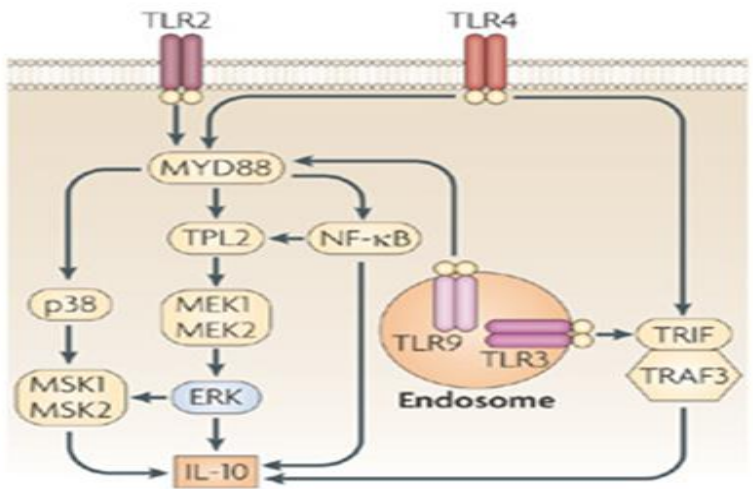

Macrophages

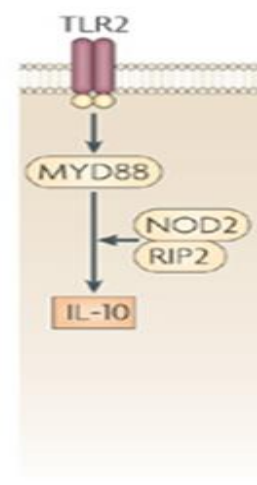

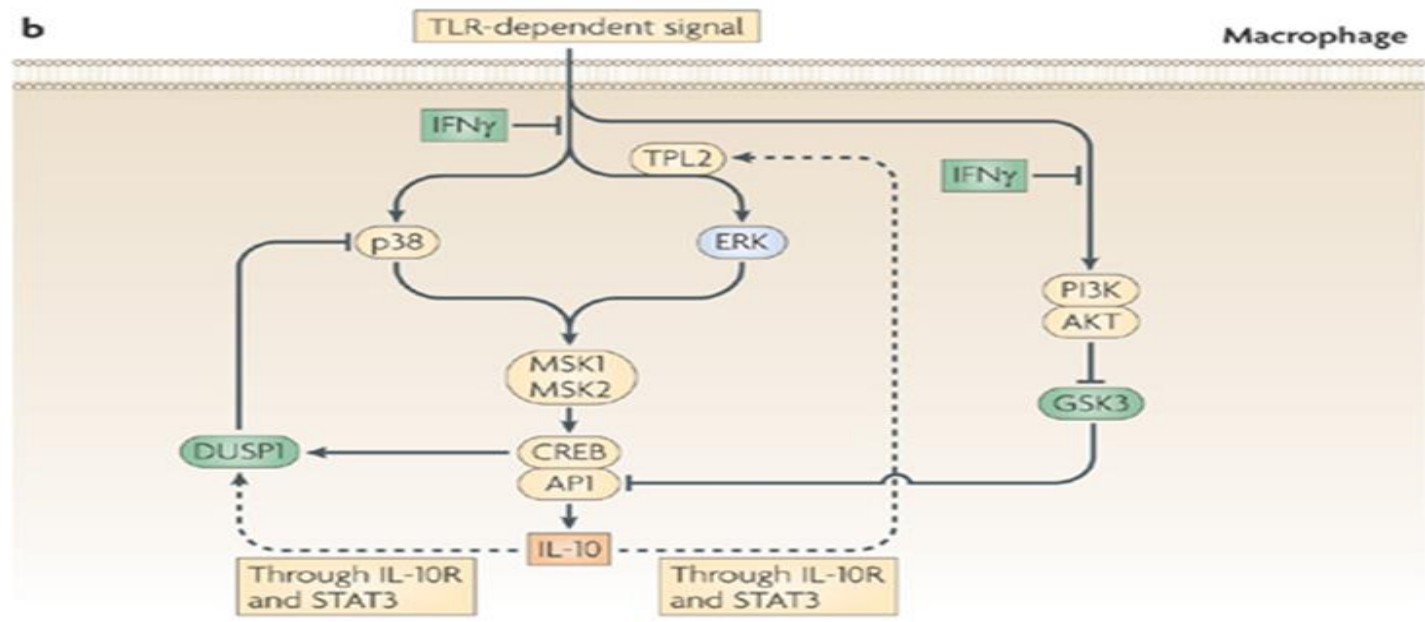

Nature Reviews | Immunology

Figure 9. (a) Expression of IL-10 on macrophage and dendritic through TLR ao non TLR path. (b) Positive and negative regulation of IL-10 (Saraiva \& O’Garra 2010). 
Titus et al. (1991) stated that the response of the first host on the infection of protozoa is a secretion of TNF- $\alpha$, IL- $1 \beta$ and IL- 6 cytokines. The combination of the activity of those three cytokines can cause leukocytosis, fever and the production of acute phase proteins. This can be explained on a study conducted by Sawitri et al. (2016) on a description of the DDY mice leucocyte infected by high virulence $T$. evansi with a leukocytosis on the first peak of parasitemia. While mice infected by low virulence $T$. evansi, the leukocytosis occurred at 8 dpi which was 2 days after the first peak of parasitemia with increasing numbers of leukocytes up to $24 \mathrm{dpi}$.

The early death of mice in this study can be described with many reasons. First, the multiplication rate of parasite on blood and central nervous system of the host can harm the host due to the excessive exploitation of the host causing severe disease and death (Biswas et al. 2001; Habila et al. 2011). Secondly, an imbalance of cytokine production of pro inflammatory cytokine such as TNF- $\alpha$, IL-6, IL-12 and IFN- $\gamma$ (Kaushik et al. 2000; Shi et al. 2003). The uncontrolled IFN- $\gamma$ production causes an imbalance in IFN- $\gamma$ and IL-10 response leading to early death (Shi et al. 2006). Third, an acute anemia related to parasitemia wave (the trypanosome in the blood) and the severity of disease (Adamu et al. 2008).

\section{CONCLUSION}

There is a difference response of pro inflammatory (IFN $\gamma$, TNF- $\alpha$ ) and anti-inflammatory cytokine between mice which infected by Bang 87 and Pml 287 T. evansi isolates. Early deaths in mice infected by Bang 87 isolate were suspected as a result of the response of systemic inflammation syndromes characterized by elevated IFN- $\gamma$ levels that were not adequately compensated by anti-inflammatory. Anemia contributes to the cause of death in mice that support multiple organ failures (multiple organ dysfunction).

\section{ACKNOWLEDGMENT}

Acknowledgements are addressed to the Indonesian Agency for Agricultural Research and Development, Ministry of Agriculture-Republic of Indonesia for the finansial support allocated in the APBN T.A 2013 where this project could be conducted. The authors acknowledge to Prof. dr. Muhammad Sadikin DSc for the discussion and Mr. Eko Setyo Purwanto, Mr. Farlin Nefho, and Mr. Edi Satria for their laboratory works.

\section{REFERENCES}

Abbas A, Litchman A. 2009. Basic immunology. Philadelphia (USA): Saunders, Elsevier.

Adamu S, Ibrahim NDG, Nok AJ, Esievo KAN. 2008. Sialyltransferase activity probably counteracts that of sialidase as one of the possible mechanisms of natural recovery or stabilization of erythrocyte mass in trypanosome-infected animals - A perspective. Afr $\mathbf{J}$ Biotechnol. 7:4992-5001.

Akira S, Uematsu S, Takeuchi O. 2006. Pathogen recognition and innate immunity. Cell. 124:783-801.

Almeida I, Camargo M, Proc'opio D. 2000. Highly purified glycosylphosphatidylinositols from Trypanosoma cruzi are potent proinflammatory agents. EMBO Journal. 19:1476-1485.

Almeida I, Gazzinelli R. 2001. Proinflammatory activity of glycosylphosphatidylinositol anchors derived from Trypanosoma cruzi: Structural and functional analyses. J Leukoc Biol. 70:467-477.

Barkhuizen M, Magez S, Atkinson RA, Brombacher F. 2007. Interleukin-12p70-dependent interferon- gamma production is crucial for resistance in African trypanosomiasis. J Infect Dis. 196:1253-1260.

Basset C, Holton J, O'Mahony R, Roitt I. 2003. Innate immunity and pathogen-host interaction. Vaccine. 21:512-513.

Biswas D, Choudhury A, Misra KK. 2001. Histopathology of Trypanosoma (Trypanozoon) evansi infection in Bandicoot Rat.I.Visceral organs. Exp Parasitol. 99:148159.

Coldewey SM, Rogazzo M, Collino M, Patel NS, Thiemermann C. 2013. Inhibition of I $\mathrm{KB}$ kinase reduces the multiple organ dysfunction caused by sepsis in the mouse. Dis Model Mech. 6:1031-1042.

Coller S, Mansfield J, Paulnock D. 2003. Glycosylinositolphosphate soluble variant surface glycoprotein inhibits IFN- $\gamma$-induced nitric oxide production via reduction in STAT1 phosphorylation in African trypanosomiasis. J Immunol. 171:1466-1472.

Darji A, Beschin A, Sileghem M, Heremans H, Brys L, De Baetselier P. 1996. In vitro simulation of immunosuppression caused by Trypanosoma brucei: active involvement of gamma interferon and tumor necrosis factor in the pathway of suppression. Infect Immun. 64:1937-1943.

Debierre-Grockiego F, Azzouz N, Schmidt J, Dubremetz JF, Geyer H, Geyer R, Weingart R, Schmidt RR, Schwarz RT. 2003. Roles of glycosylphosphatidylinositols of Toxoplasma gondii. Induction of tumor necrosis factoralpha production in macrophages. J Biol Chem. 278:32978-32993. 
Eckersall PD, Gow JW, McComb C, Bradley B, Rodgers J, Murray M, Kennedy PG. 2001. Cytokines and the acute phase response in post-treatment reactive encephalopathy of Trypanosoma brucei brucei infected mice. Parasitol Int. 50:15-26.

Gao W, Wortis HH, Pereira MA. 2002. The Trypanosoma cruzi trans-sialidase is a $\mathrm{T}$ cell-independent $\mathrm{B}$ cell mitogen and an inducer of non-specific Ig secretion. Int Immunol. 14:299-308

Gazzinelli R, Denkers E. 2006. Protozoan encounters with Toll-like receptor signalling pathways: implications for host parasitism. Nat Rev Immunol. 6:895-906.

Ghalib HW, Ahmed M, Steven G. 1993. Interleukin 10 Production correlates with pathology in human leishmania donovani infections. J Clin Invest. 92:324-329.

Groenveld HF, Januzzi JL, Damman K, van Wijngaarden J, Hillege HL, van Veldhuisen DJ, van der Meer P. 2008. Anemia and mortality in heart failure patients a systematic review and meta-analysis. J Am Coll Cardiol. 52:818-827.

Guilliams M, Movahedi K, Bosschaerts T, VandenDriessche T, Chuah MK, Hérin M, Acosta-Sanchez A, Ma L, Moser M, Van Ginderachter JA, Brys L, De Baetselier P, Beschin A. 2009. IL-10 dampens TNF/inducible nitric oxide synthase-producing dendritic cell-mediated pathogenicity during parasitic infection. J Immunol. 182:1107-1118.

Habila N, Inuwa MH, Aimola IA, Udeh MU, Haruna E. 2011. Mechanisms of Trypanosoma evansi infections. Res Vet Sci. 93:13-17.

Harris TH, Cooney NM, Mansfield JM, Paulnock DM. 2006. Signal transduction, gene transcription, and cytokine production triggered in macrophages by exposure to trypanosome DNA. Infect Immun. 74:4530-4537.

Hertz CJ, Filutowicz H. 1998. Resistance to the African trypanosomes is IFN- gamma dependent. J Immunol. 161:6775-6783.

Jelkmann W. 1998. Proinflammatory cytokines lowering erythropoietin production. J Interferon Cytokine Res. 18:555-559.

Jittapalapong $\mathrm{S}$, Pinyopanuwat $\mathrm{N}$, Inpankaew $\mathrm{T}$, Sangvaranond A, Phasuk C, Chimnoi W, Kengradomkij C, Kamyingkird K, Sarataphan N, Desquesnes M, Arunvipas P. 2009. Prevalence of Trypanosoma evansi infection causing abortion in dairy cows in Central Thailand. Kasetsart J Nat Sci. 43:53-57.

Kaushik RS, Uzonna JE, Zhang Y, Gordon JR, Tabel H. 2000. Innate resistance to experimental African trypanosomiasis: differences in cytokine (TNF-alpha, IL-6, IL-10 and IL-12) production by bone marrowderived macrophages from resistant and susceptible mice. Cytokine. 12:1024-1034.

Kitani H, Black SJ, Nakamura Y, Naessens J, Murphy NB, Yokomizo Y, Gibson J, Iraqi F. 2002. Recombinant tumor necrosis factor alpha does not inhibit the growth of African trypanosomes in axenic cultures. Infect Immun. 70:2210-2214.

Krishnagopalan S, Kumar A, Parrillo JE, Kumar A. 2002. Myocardial dysfunction in the patient with sepsis. Curr Opin Crit Care. 8:376-388.

Larroche C, Mouthon L. 2004. Pathogenesis of hemophagocytic syndrome (HPS). Autoimmun Rev. 3:69-75.

Mabbott NA, Coulson PS, Smythies LE, Wilson RA, Sternberg JM. 1998. African trypanosomose infections in mice that lack the interferon-c receptor gene: nitric oxide-dependent and independent suppression of T-cell proliferative responses and the development of anaemia. Immunol. 94:476-480.

Magez S, Radwanska M, Drennan M, Fick L, Baral TN, Brombacher F, De Baetselier P. 2006. Interferongamma and nitric oxide in combination with antibodies are key protective host immune factors during Trypanosoma congolense Tc13 infections. J Infect Dis. 193:1575-1583.

Magez S, Stijlemans B, Caljon G, Eugster HP, De Baetselier P. 1993. Murine tumour necrosis factor plays a protective role during the initial phase of the experimental infection with Trypanosoma brucei brucei. Parasite Immunol. 15:635-641.

Magez S, Truyens C, Merimi M, Radwanska M, Stijlemans B, Brouckaert P, Brombacher F, Pays E, De Baetselier P., 2004. P75 tumor necrosis factor-receptor shedding occurs as a protective host response during African trypanosomiasis. J Infect Dis. 189:527-539.

Magez S, Radwanska M, Drennan M, Fick L, Baral TN, Allie N, Jacobs M, Nedospasov S, Brombacher F, Ryffel B, De Baetselier P. 2007. Tumor necrosis factor (TNF) receptor-1 (TNFp55) signal transduction and macrophage-derived soluble TNF are crucial for nitric oxide-mediated Trypanosoma congolense parasite killing. J Infect Dis. 196:954-962.

Magez S, Radwanska M, Beschin A, Sekikawa K, De Baetselier P. 1999. Tumor necrosis factor alpha is a key mediator in the regulation of experimental Trypanosoma brucei infections Infections. Infect Immun. 67:31283132.

Magez S, Geuskens M, Beschin A. 1997. Specific uptake of tumor necrosis factor- $\alpha$ is involved in growth control of Trypanosoma brucei. J Cell Biol. 137:715-727.

Maina N, Ngotho JM, Were T, Thuita JK, Mwangangi DM, Kagira JM, Ndung'u JM, Sternberg J. 2004. Proinflammatory cytokine expression in the early phase of Trypanosoma brucei rhodesiense infection in vervet monkeys (Cercopithecus aethiops). Infect Immun. 72:3063-3065.

Medzhitov R, Janeway CJ. 2000. Innate immunity. N Engl J Med. 343:338-344.

Mekata H, Konnai S, Mingala CN, Abes NS, Gutierrez CA, Dargantes AP, Witola WH, Inoue N, Onuma M, Murata S, Ohashi K. 2013. Isolation, cloning, and pathologic 
analysis of Trypanosoma evansi field isolates. Parasitol Res. 112:1513-1521.

Murray RK, Granner DK, Mayes PA, Rodwell. 2003. Harper's illustrated biochemistry. 26th ed. USA: Appleton \& Lange.

Naessens J, Kitani H, Momotani E, Sekikawa K, Nthalea JM, Iraqi F. 2004. Susceptibility of TNF- $\alpha$-deficient mice to Trypanosoma congolense is not due to a defective antibody response. Acta Trop. 92:193-203.

Naessens J, Kitani H, Nakamura Y. 2005. TNF- a mediates the development of anaemia in a murine Trypanosoma brucei rhodesiense infection, but not the anaemia associated with a murine Trypanosoma congolense infection. Clin Exp Immunol. 139:405-410.

Namangala B, De Baetselier P, Noël W, Brys L, Beschin A. 2001a. Alternative versus classical macrophage activation during experimental African trypanosomosis. J Leuko Biol. 69:387-396.

Namangala B, Noël W, De Baetselier P, Brys L, Beschin A. 2001b. Relative contribution of interferon-gamma and interleukin-10 to resistance to murine African trypanosomosis. J Infect Dis. 183:1794-1800.

Namangala B, Baetselier PD, Beschin A. 2009. Both type- I and type-II responses contribute to murine trypanotolerance. J Vet Med Sci. 71:313-318.

Noël W, Hassanzadeh G, Raes G, Namangala B, Daems I, Brys L, Brombacher F, Baetselier PD, Beschin A. 2002. Infection stage-dependent modulation of macrophage activation in Trypanosoma congolense-resistant and susceptible mice. Infect Immun. 70:6180-6187.

Paulnock DM, Coller SP. 2001. Analysis of macrophage activation in African trypanosomiasis. J Leukoc Biol. 69:685-690.

Payne RC, Sukanto IP, Partoutomo S, Jones TW. 1994. Efficacy of cymelarsan treatment of suramin resistant Trypanosoma evansi in cattle. Trop Anim Health Prod 26:92-94

Payne RC, Sukanto IP, Bazeley K, Jones TW. 1993. The effect of Trypanosoma evansi infection on the oestrous cycle of Friesian Holstein heifers. Vet Parasitol. $51: 1-11$.

Quan N, Mhlanga JD, Whiteside MB, McCoy AN, Kristensson K, Herkenham M. 1999. Chronic overexpression of proinflammatory cytokines and histopathology in the brains of rats infected with Trypanosoma brucei. J Comp Neurol. 414:114-130.

Ralph P, Nakoinz I, Sampson-Johannes A, Fong S, Lowe D, Min HY, Lin L. 1992. IL-10, T lymphocyte inhibitor of human blood cell production of IL-1 and tumor necrosis factor. J Immunol. 148:808-814.

Reed S, Pihl D, Grabstein KH. 1989. Immune deficiency chronic Trypanosoma cruzi infection recombinant IL-1 restores Th function for antibody production. J Immunol. 142:2067-2071.
Saraiva M, O'Garra A. 2010. The regulation of IL-10 production by immune cells. Nat Rev Immunol. 10:170-181.

Sawitri DH. 2016. Virulence study of Trypanosoma evansi isolates from Indonesia and identification of molecular marker based on microsatellite DNA and cytokine profile analyses in mice (Mus musculus) (Thesis). [Depok (Indones)]: University of Indonesia.

Sher A, Coffman RL. 1992. Regulation of immunity to parasites by $\mathrm{T}$ cells and $\mathrm{T}$ cell-derived cytokines. Ann Rev Immunol. 10:385-409.

Shi M, Wei G, Pan W, Tabel H. 2006. Experimental African trypanosomiasis: a subset of pathogenic, IFNgammaproducing, MHC class II-restricted CD4+ T cells mediates early mortality in highly susceptible mice. J Immunol. 176:1724-1732.

Shi M, Wei G, Pan W, Tabel H. 2005. Impaired Kupffer cells in highly susceptible mice infected with Trypanosoma congolense. Infect Immun. 73:8393-8396.

Shi M, Wei G, Pan W, Tabel H. 2004. Trypanosoma congolense infections: antibody-mediated phagocytosis by Kupffer cells. J Leuko Biol. 76:399-405.

Shi M, Pan W, Tabel H. 2003. Experimental African trypanosomiasis: IFN-gamma mediates early mortality. Eur J Immunol. 33:108-118.

Shoda L, Kegerreis K, Suarez C. 2001. DNA from protozoan parasites Babesia bovis, Trypanosoma cruzi, and $T$. brucei is mitogenic for B lymphocytes and stimulates macrophage expression of interleukin-12, tumor necrosis factor alpha, and nitric oxide. Infect Immun. 69:2162-2171.

Sileghem M, Darji A, Hamers R, De Baetselier P. 1989. Modulation of IL-1 production and IL-1 release during experimental trypanosome infections. Immunol. $68: 137-139$

Sileghem M, Darji A, Instituut PDEB. 1991. In vitro simulation of immunosuppression caused by Trypanosoma brucei. Immunol. 73:246-248.

Silva JS, Morrissey PJ, Grabstein KH, Mohler KM, Anderson D, Reed SG. 1992. Interleukin 10 and interferon g regulation of experimental Trypanosoma cruzi infection. J Exp Med. 175:169-174.

Stijlemans B, Vankrunkelsven A, Caljon G, Bockstal V, Guilliams M, Bosschaerts T, Beschin A, Raes G, Magez S, De Baetselier P. 2010. The central role of macrophages in trypanosomiasis-associated anemia: rationale for therapeutical approaches. Endocr Metab Immune Disord Drug Targets. 10:71-82.

Titus RG, Sherry B, Cerami A. 1991. The involvement of TNF, IL-1 and IL-6 in the immune response to protozoan parasites. Trends Immunol. 12:A13-A16.

Trinchieri G. 1995. Interleukin-12: A proinflammatory cytokine with immunoregulatory functions that bridge innate resistance and antigen-specific adaptive immunity. Ann Rev Immunol. 13:251-276. 
Uzonna JE, Kaushik RS, Zhang Y, Gordon JR, Tabel H. 1998. Experimental murine Trypanosoma congolense infections. II. Role of splenic adherent CD3+Thy1.2+ TCR-alpha beta- gamma delta- $\mathrm{CD} 4+8-$ and CD3+Thy1.2+ TCR-alpha beta- gamma delta- CD4-8cells in the production of IL-4, IL-10, and IFN-gamma and in trypanosome-elicited immunosuppression $\mathrm{J}$ Immunol. 161:6189-6197.

Verdillo JC, Lazaro JV, Abes NS, Mingala CN. 2012. Comparative virulence of three Trypanosoma evansi isolates from water buffaloes in the Philippines. Exp Parasitol. 130:130-134. 